\title{
Pengaruh Model Cooperative Learning Tipe Student Team Achievement Division (STAD) Terhadap Aktivitas dan Hasil Belajar IPA
}

\author{
Agus Aryanto*, Sucipto, Muhajir \\ Magister Teknologi Pendidikan, Universitas Dr. Soetomo \\ *Corresponding Author. Email: agus.aryanto@gmail.com
}

\begin{abstract}
The purpose of this study was to examine the effect of the cooperative learning model of the Team Achievement Division (STAD) type on the activities and science learning outcomes of Class VIII students of SMP Negeri 2 Tanjungbumi. The quantitative approach was used with a quasiexperimental technique where the control group was not chosen at random. The instruments in this study were questionnaires, observation sheets, and tests. This study uses data analysis with the t-test formula. Based on the analysis of the data, it was concluded that there was an effect of the cooperative learning model of the Team Achievement Division (STAD) type on the activities and learning outcomes of Science Class VIII students of SMP Negeri 2 Tanjungbumi.
\end{abstract}

\begin{abstract}
Abstrak: Tujuan Penelitian ini adalah untuk menguji pengaruh model cooperative learning Student tipe Team Achievement Division (STAD) terhadap aktivitas dan hasil belajar IPA siswa Kelas VIII SMP Negeri 2 Tanjungbumi. Pendekatan kuantitatif dugunakan dengan teknik quasi eksperimen dimana kelompok kontrol tidak dipilih secara random. Instrumen dalam penelitian ini adalah angket, lembar observasi, dan tes. Penelitian ini menggunakan analisis data dengan rumus t-test. Berdasarkan analisis data diperoleh kesimpulan bahwa terdapat pengaruh model cooperative learning Student tipe Team Achievement Division (STAD) terhadap aktivitas dan hasil belajar IPA siswa Kelas VIII SMP Negeri 2 Tanjungbumi.
\end{abstract}

\section{Article History}

Received: 03-03-2021

Reviewed: 16-07-2021

Accepted: 21-08-2021

Published: 18-10-2021

\section{Key Words}

Cooperative Learning,

STAD, Activities \&

Learning Outcomes.

\section{Sejarah Artikel \\ Diterima: 03-03-2021 \\ Direview: 16-07-2021 \\ Disetujui: 21-08-2021 \\ Diterbitkan: 18-10-2021 \\ Kata Kunci \\ STAD, Hasil Belajar, \\ Model Pembelajaran}

How to Cite: Aryanto, A., Sucipto, S., \& Muhajir, M. (2021). Pengaruh Model Cooperative Learning Tipe Student Team Achievement Division (STAD) Terhadap Aktivitas dan Hasil Belajar IPA. Jurnal Teknologi Pendidikan : Jurnal Penelitian dan Pengembangan Pembelajaran, 6(2), 185-192. doi:https://doi.org/10.33394/jtp.v6i2.3537

https://doi.org/10.33394/jtp.v6i2.3537

This is an open-access article under the CC-BY-SA License.

\section{Pendahuluan}

IPA merupakan mata pelajaran yang memberikan pengetahuan tentang alam sekitar beserta isinya. Hal ini berarti IPA mempelajari semua benda yang ada di alam, peristiwa, dan gejala-gejala yang muncul di alam. Untuk itu maka pembelajaran IPA sangat penting untuk dipelajari mulai dari tingkat sekolah dasar sampai ke perguruan tinggi. Tujuan pembelajaran IPA di SMP selain untuk meningkatkan keyakinan terhadap kebesaran Tuhan Yang Maha Esa, juga mengembangkan pemahaman tentang berbagai macam gejala alam, konsep dan prinsip IPA yang bermanfaat dan dapat diterapkan dalam kehidupan sehari-hari serta meningkatkan pengetahuan, konsep dan keterampilan IPA sebagai dasar untuk melanjutkan pendidikan ke jenjang selanjutnya (Indrayani, 2014). Upaya yang dilakukan pemerintah untuk meningkatkan mutu pendidikan, termasuk pendidikan IPA adalah pembaharuan kurikulum.

Berkaitan dengan pembaharuan kurikulum, sekarang ini pemerintah sedang menerapkan Kurikulum 2013 dengan pendekatan tematik integratif. Model pembelajaran IPA terpadu merupakan salah satu model pembelajaran yang dianjurkan kurikulum untuk 
diaplikasikan pada tingkat SMP, karena model pembelajaran IPA terpadu merupakan suatu pendekatan pembelajaran yang memungkinkan peserta didik secara aktif mencari, menggali dan menemukan konsep serta prinsip secara holistik dan otentik (Puskur, 2006). Pembelajaran IPA terpadu dalam arti luas meliputi pembelajaran yang terpadu dalam satu disiplin ilmu, terpadu antar mata pelajaran. Pembelajaran terpadu menghubungkan suatu konsep dengan konsep-konsep lain yang sesuai dengan kebutuhan peserta didik, terjalinnya hubungan antar setiap konsep secara terpadu akan memberi ruang kepada peserta didik untuk terlibat aktif dalam proses pembelajaran dan memotivasi peserta didik untuk memahami konsep-konsep yang mereka pelajari (Puskur, 2006). Pembelajaran IPA secara terpadu sangat memungkinkan hasil belajar yang diperoleh siswa akan lebih bermakna dibandingkan dengan belajar konsep secara terpisah. Demikian pula dengan pembelajaran IPA terpadu, tumpang tindih materi dapat diminimalkan atau dihilangkan sehingga dapat memberikan kesempatan mengembangkan kecakapan berpikir lebih banyak dalam proses pembelajaran.

Proses pembelajaran ilmu pengetahuan alam (IPA) adalah proses aktif yang menekankan pada sesuatu yang dilakukan siswa, bukan pada sesuatu yang dilakukan guru Metode ceramah dalam pembelajaran masih sangat dominan dilakukan dengan komunikasi satu arah. Kepada siswa hanya disajikan fakta-fakta yang merupakan produk ilmiah, sehingga tidak dapat menarik minat. Dengan demikian ketiga kerangka dasar dalam pendidikan sains yaitu sikap, proses dan produk ilmiah tidak diterapkan, sehingga pembelajaran hanya menyajikan fakta fakta belaka dan cenderung bersifat hafalan (Agustina, $\mathrm{R}, 2018$ )

Pada pembelajaran IPA model pembelajaran konvensional (ceramah) kurang memberikan kesempatan siswa untuk aktif dalam pembelajaran sehingga siswa cenderung dian dan hanya mendengarkan penjelasan dari guru saja dan pembelajarn konvensional itu kurang memfasilitasi siswa untuk kerjasama tim antar siswa satu dengan yang lain. Permasalahan yang lain adalah guru juga mengalami kesulitan berupa karakteristik materi IPA sendiri, yang umumnya dikenal sulit dikalangan siswa (Muldayanti, N, 2013). Model yang dirasa tepat untuk mengatasi permasalahan diatas adalah dengan menerapkan model pembelajaran kooperatif student team achievment divisions (STAD) (Agustina, R, 2018).

Berdasarkan observasi dan pengalaman lapangan yang dilakukan di SMP, pembelajaran IPA yang diharapkan oleh kurikulum yaitu pembelajaran IPA menggunakan pendekatan saintifik, ternyata masih dilakukan secara konvensional. Di lapangan sebagian besar guru belum mempraktekkan model pembelajaran IPA yang menggambarkan pendekatan saintifik. Konsep-konsep fisika, kimia maupun biologi masih diajarkan secara konvensional dengan cara ceramah, tanya jawab, dan penugasan. Padahal dengan pendekatan saintifik dalam pembelajaran IPA diharapkan siswa dapat mempelajari dan terlibat secara langsung dalam proses pembelajaran dan akan lebih bermakna. Pada kenyataannya sebagian besar guru mengalami kesulitan untuk dapat merancang pembelajaran IPA yang mencerminkan aktivitas kegiatan yang berpedoman pada pendekatan saintifik. Hal ini dapat disebabkan karena belum banyaknya contoh konkrit yang dapat mereka aplikasikan. Selain itu belum adanya buku IPA SMP yang dirancang khusus yang mencerminkan tahapan pembelajaran saintifik.

Pembelajaran menggunakan model pembelajaran yang konvensional melalui ceramah dan penugasan mengakibatkan peran guru menjadi sangat dominan. Siswa menjadi pembelajar yang pasif dan hanya melakukan aktivitas yang diinstruksikan oleh guru. Siswa menyimak penjelasan guru dan kemudian mengerjakan latihan soal. Kurangnya inovasi pembelajaran menyebabkan siswa tidak memiliki ruang yang cukup agar dapat belajar secara 
mandiri dan mampu mengkonstruksikan pengetahuan yang dipelajari serta menjadi pembelajar yang terampil dalam menyelesaikan berbagai persoalan pembelajaran. Terkadang untuk mengembangkan kemampuan siswa secara optimal, guru harus memberikan tugas dan tantangan yang berat agar mereka terbiasa berpikir di bawah tekanan, berpikir analitis, berpikir kreatif, sehingga mampu mengeluarkan seluruh kemampuan terbaik yang dimiliki oleh siswa. Pembelajaran konvensional menyebabkan siswa tidak dapat berinteraksi secara maksimal dalam proses pembelajaran. Siswa belajar secara individual dan kondisi tersebut menyebabkan ketimpangan yang sangat jauh antara siswa yang memiliki kemampuan intelektual yang tinggi dan rendah.

Proses pembelajaran akan memberikan dampak terhadap hasil belajar siswa. hasil belajar tidak hanya dilihat dari angka yang diperoleh pada akhir pembelajaran namun pada bagaimana siswa mampu memperoleh bilai tersebut dan korelasinya terhadap aktivitas siswa dalam pembelajaran. pembelajaran yang selama ini menggunakan model pembelajaran konvensional memberikan dampak terhadap banyaknya siswa yang masih memperoleh nilai hasil belajar IPA di bawah kriteria ketuntasan minimal (KKM), dimana guru telah menetapkan KKM mata pelajaran IPA 75. Namun pada kenyataannya masih terdapat 12 siswa kelas VIIIA atau 48\% dari seluruh jumlah siswa di kelas masih memiliki nilai di bawah KKM dan sebanyak 16 siswa kelas VIIIB atau 56\% dari seluruh jumlah siswa di kelas yang juga masih memiliki nilai dibawah KKM.

Sehubungan dengan realitas yang telah diuraikan di atas, maka peneliti tertarik untuk memahami lebih dalam tentang model cooperative tipe STAD dalam proses belajar IPA dan melihat pengaruhnya terhadap aktivitas dan hasil belajar IPA siswa kelas VIII di SMP Negeri 2 Tanjungbumi. Model pembelajaran STAD merupakan model pembelajaran cooperative yang menekankan pada kerja sama siswa dalam kelompok untuk mendukung pencapaian tujuan pembelajaran. Guru yang menggunakan STAD, juga mengacu kepada belajar kelompok murid, menyajikan informasi akademik baru kepada murid setiap minggu menggunakan presentasi verbal atau teks. Guru membagi murid menjadi kelompok-kelompok kecil yang terdiri dari 4-5 orang dan terdiri laki-laki dan perempuan yang berasal dari berbagai suku, memiliki kemampuan tinggi, sedang, rendah (Kristin, 2016). Pengajaran cooperative learning telah menunjukkan dapat meningkatkan hubungan sosial dan pembelajaran, dari pada pengajaran tradisional (Muldayanti, N, 2013).

Gagasan utama STAD adalah untuk memotivasi siswa supaya dapat saling mendukung dan membantu satu sama lain dalammenguasai kemampuan yang diajarkan oleh guru (Agustina, R, 2018). Tujuan pembelajaran kooperatif tipe STAD dapat lebih membiasakan kepada siswa untuk belajar berkelompok dalam rangka memecahkancahkan masalah atau mengerjakan tugas. Disamping itu pembelajaran kooperatif tipe STAD dapat membantu siswa memahami konsep-konsep pelajaran yang sulit serta menumbuhkan kemampuan kerjasama, berpikir kritis, dan mengembangkan sikap sosial siswa (Muldayanti, N, 2013). Belajar secara berkelompok dapat menumbuhkan sikap sosial siswa dan saling membantu untuk memecahkan masalah pembelajaran sehingga diharapkan mampu memperoleh hasil belajar yang maksimal.

Belajar pada hakikatnya adalah aktivitas yang dilakukan oleh siswa dalam rangka mengembangkan kemampuan yang dimiliki untuk menguasai komepetensi yang diharapkan. Oleh sebab itu, siswa dihrapkan aktif dan terlibat secara fisik dan mental selama proses pembelajaran. untuk mewujudkan hal tersebut, maka pemilihan model pembelajaran yang sesuai dapat menentukan kondisi yang diinginan. Berdasarkan hasil pengamatan yang dilakukan peneliti terhadap kegiatan siswa dalam proses pembelajaran menggunakan model 
STAD banyak siswa semakin aktif dalam belajar (Agustina, R, 2018) Pembelajaran yang dirasa cocok untuk mengaktifkan siswa adalah pembelajaran kooperatf tipe STAD Ketika siswa terlibat aktif dan mampu menguasai berbagai pengetahuan dan keterampilan dalam proses pembelajaran, maka siswa akan lebih memudah menjawab atau menyelesaikan berbagai masalah atau tugas belajar sehingga memperoleh nilai di atas kriteria ketuntasan minimal. Hasil belajar siswa mengalami peningkatan dengan menggunakan model pembelajaran koopertif STAD Dari berbagai uraian tersebut, model pembelajaran kooperatif STAD mampu meningkatkan aktvitas dan hasil belajar siswa.

Student Teams Achievement Division (STAD) merupakan salah satu metode atau pendekatan dalam pembelajaran kooperatif yang sederhana dan baik untuk guru yang baru mulai menggunakan pendekatan kooperatif dalam kelas, STAD juga merupakan suatu metode pembelajaran kooperatif yang efektif. STAD merupakan salah satu model pembelajaran kooperatif yang memfokuskan pembelajaran pada kerjasama tim dalam mencapai tujuan pembelajaran. Guru yang menggunakan STAD, juga mengacu kepada belajar kelompok murid, menyajikan informasi akademik baru kepada murid setiap minggu menggunakan presentasi verbal atau teks. Guru membagi murid menjadi kelompok-kelompok kecil yang terdiri dari 4-5 orang dan terdiri laki-laki dan perempuan yang berasal dari berbagai suku, memiliki kemampuan tinggi, sedang, rendah (Kristin, 2016).

Faktor keberhasilan proses pembelajaran selain metode pembelajaran yang digunakan, keberhasilan proses pembelajaran juga banyak ditentukan oleh keingintahuan dan minat belajar siswa (Muldayanti, N, 2013). Model pembelajaran diharapkan mampu meningkatkan motivasi dan minat belajar siswa sehingga terlibat secara aktif dalam setiap kegiatan pembelajaran. Gagasan utama STAD adalah untuk memotivasi siswa supaya dapat saling mendukung dan membantu satu sama lain dalammenguasai kemampuan yang diajarkan oleh guru Dalam STAD, para siswa dibagi dalam tim belajar yang terdiri atas empat orang yang berbeda-beda tingkat kemampuan, jenis kelamin dan latar belakang etniknya. Guru menyampaikan pelajaran, lalu siswa bekerja dalam tim mereka untuk memastikan bahwa semua anggota tim telah menguasai pelajaran (Agustina, R, 2018).

Sintaks pembelajaran kooperatif tipe STAD antara lain, 1) presentasi kelas, 2) tim, 3) kuis, 4) skor kemajuan individu, 5) rekognisi tim, dan 6) penghargaan kelompok (Suyitno dan Rochmad, 2015). Pembelajaran kooperatif tipe STAD dicirikan oleh suatu struktur tugas, tujuan dan penghargaan kooperatif. Mahasiswa bekerja sama dalam situasi semangat pembelajaran kooperatif seperti membutuhkan kerja sama untuk mencapai tujuan bersama dan mengkoordinasikan usahanya untuk menyelesaikan tugas

Aktivitas belajar merupakan kegiatan yang mengarah pada proses pembelajaran, seperti bertanya, mengajukan pendapat, mengerjakan tugas-tugas, serta menjawab pertanyaan guru dengan baik (Nurmala, 2014). Aktivitas yang timbul dari siswa yang mengakibatkan terbentuknya pengetahuan dan keterampilan yang akan mengarah pada peningkatan prestasi. Aktivitas siswa dalam pembelajaran dapat menyebabkan pembelajaran di sekolah menjadi lebih hidup sebagaimana aktivitas dalam kehidupan di masyarakat karena siswa aktif dalam belajar (mencari pengalaman) dan langsung mengalami sendiri kegiatan pembelajaran. Menurut Sardiman (2008) aktivitas belajar dapat digolongkan dalam beberapa klasifikasi sebagai berikut. (a) Visual Activities, yaitu membaca, memperlihatkan gambar, demonstrasi, percobaan, pekerjaan orang lain. (b) Oral Activities, yaitu menyatakan, merumuskan, bertanya, member saran, wawancara, diskusi dan mengeluarkan pendapat, interupsi. (c) Listening Activities, yaitu mendengarkan uraian, percakapan dan pidato, musik. (d) Writing Activities, yaitu menulis cerita, karangan, laporan, angket, menyalin. (e) Drawing Activities, 
yaitu menggambar, membuat grafik, peta, dan diagram. (f) Motor Activities, yaitu seperti melakukan percobaan, membuat konstruksi, model mereparasi, bermain, berkebun, danbeternak.(g) Mental Activities, yaitu menanggapi, mengingat, memecahkan soal, menganalisis, melihat hubungan, dan mengambil keputusan. (h) Emotional Activities, yaitu seperti perhatian, merasa bosan, gembira, berani, tenang, gugup, bersemangat, bergairah.

Indikator yang digunakan peneliti untuk mengembangkan instrument penelitian terdiri atas beberapa indikator yang dapat digunakan dalam mengamati aktivitas belajar siswa yaitu sebagai berikut. (1) Antusiasme siswa dalam mengikuti kegiatan pembelajaran, (2) Interaksi siswa dengan guru, (3) Interaksi siswa dengan siswa lain, (4) Kerjasama kelompok, (5) Aktivitas siswa dalam diskusi kelompok, (5) Aktivitas siswa dalam melaksanakan pembelajaran, (6) Keterampilan siswa dalam menggunakan alat peraga, (7) Partisipasi siswa dalam menyimpulkan materi pembelajaran. Indikator untuk mengamati aktivitas belajar siswa juga dikemukakan oleh Departemen Pendidikan Nasional, dengan menyusun dan menerbitkan Teknis Penilaian Afektif di SMK meliputi sebagai berikut. (1) Antusiasme siswa dalam mengikuti kegiatan pembelajaran, (2) Interaksi siswa dengan guru, (3) Interaksi antar peserta didik, (4) Kerjasama kelompok, (5) Aktifitas peserta didik dalam kelompok, (6) Melaksanakan praktek denga nmenggunakan media, (7) Partisipasi peserta didik dalam menyimpulkan hasil pembahasan

IPA merupakan salah satu mata pelajaran yang sangat penting dan selalu diberikan pada setiap jenjang pendidikan tersebut. Tetapi, pembelajaran IPAhingga dewasa ini sering melupakan dimensi proses yang ada. Pembelajaran dilakukan lebih mengutamakan dimensi produk yang berupa hasil pada buku saja. Dimensi proses sangat penting dalam menunjang perkembangan siswa memperoleh pengetahuan tetapi juga memperoleh kemampuan untuk menggali dan menemukan pengetahuan itu sendiri. Poerwanto (Poerwanto, 2007) memberikan pengertian prestasi belajar yaitu " hasil yang dicapai oleh seseorang dalam usaha belajar sebagaimana yang dinyatakan dalam raport". Prestasi belajar adalah suatu bukti keberhasilanbelajar atau kemampuan seseorang siswa dalam melakukan kegiatan belajar sesuai dengan bobot yang dicapainya. prestasi belajar adalah kesempurnaan yangdicapai seseorang dalam berfikir, merasa danberbuat, prestasi belajar dikatakan sempurna apabila memenuhi tiga aspek yakni: kognitif, afektif danpsikomotor, sebaliknya dikatakan prestasi kurang memuaskan jika seseorang belum mampu memenuhi target dalam ketiga kriteria tersebut.

Menurut Syaiful Bahri Djamarah (Djamarah, 2012) menyatakan hasil belajar adalah "perubahan yang terjadi sebagai akibat dari kegiatan belajar yang telah dilakukan oleh individu". Perubahan tingkah laku yang dialami oleh siswa tergantung dari apa yang ia pelajari selama kurun beberapa waktu. Out put (hasil) yang diperoleh siswa biasanya perubahan tingkah laku yang menyangkut aspek kognitif, afektif, dan psikomotor yang disimbolkan dengan angka atau nilai. Hasil belajar sama dengan prestasi belajar, yang berarti penilaian hasil belajar yang dinyatakan dalam bentuk angka, huruf atau kalimat yang mencerminkan hasil yang sudah dicapai siswa dalam periode tertentu (Negoro, S, 2004).

Berdasarkan pengertian diatas, maka dapat dijelaskan bahwa prestasi belajar merupakan tingkatkemanusiaan yang dimiliki siswa dalam menerima,menolak dan menilai informasi-informasi yangdiperoleh dalam proses belajar mengajar. Prestasibelajar seseorang sesuai dengan tingkatkeberhasilan sesuatu dalam mempelajari materipelajaran yang dinyatakan dalam bentuk nilai atauraport setiap bidang studi setelah mengalami prosesbelajar mengajar. Prestasi belajar siswa dapatdiketahui setelah diadakan evaluasi. Hasil darievaluasi dapat memperlihatkan tentang tinggi ataurendahnya prestasi belajar siswa. 


\section{Metode Penelitian}

Jenis penelitian yang digunakan dalam penelitian ini adalah quasi experimental Design dengan nonequivalent control group design. Populasi penelitian ini adalah siswa-siswa Kelas VIII SMP Negeri 2 Tanjungbumi yang berjumlah 50 siswa yang terdiri dari 25 orang siswa kelas VIIIA dan 25 orang lagi kelas VIIIB. Peneliti menggunakan lembar angket untuk pelaksanaan model cooperative learning Student Team Achievement Division (STAD), lembar observasi untuk aktivitas siswa, dan soal tes untuk mengumpulkan data hasil belajar siswa.Data penelitian diperoleh oleh peneliti menggunakan instrumen penelitian yang telah melalui uji validitas dan reliabilitas. Data diperoleh dari dua aktivitas yang berbeda, dimana aktivitas pengumpulan data yang pertama dilakukan pada kelas ekperimen. Kelas eksperimen merupakan kelas yang menggunakan model pembelajaran kooperatif STAD dan kelas kontrol merupakan kelas yang tidak mendapat perlakuan atau menggunakan model pembelajaran konvensional. model pembelajaran konvensional yang dilakukan adalah ceramah dan pemberian tugas. Penelitian ini menggunakan analisis data dengan rumus $t$-test.

\section{Hasil Penelitian dan Pembahasan}

Untuk mengetahui pengaruh model cooperative learning Student Team Achievement Division (STAD) terhadap aktivitas belajar IPA, peneliti melakukan uji beda menggunakan rumus t-test.Hasil analisis data t-test kemudian dibandingkan dengan distribusi nilai t pada tabel untuk taraf signifikan 5\% dan jumlah sampel 25 orang. berdasarkan patokan tersebut, maka peneliti menyatakan bahwa nilai t hitung (2.813) lebih besar dari pada t tabel (2.060). Dengan demikian dapat dinyatakan bahwa terdapat pengaruh yang signifikan antara penerapan model pembelajaran koooperatif ttipe STAD terahadap aktivitas belajar siswa kelas VIII SMP Negeri 2 Tanjungbumi.

Pemilihan teknik statistik disesuaikan dengan tujuan yang ingin diperoleh. Untuk mengetahui pengaruh model cooperative learning Student Team Achievement Division (STAD) terhadap hasil belajar IPA, peneliti melakukan uji beda menggunakan rumus ttest.Hasil analisis uji t kemudian dibandingkan dengan distribusi nilai t pada tabel untuk taraf signifikan 5\% dan jumlah sampel 25 orang. berdasarkan patokan tersebut, maka peneliti menyatakan bahwa nilai t hitung (2.274) lebih besar dari pada t tabel (2.060). Dengan demikian dapat dinyatakan bahwa terdapat pengaruh yang signifikan antara penerapan model pembelajaran koooperatif ttipe STAD terahadap hasil belajar siswa kelas VIII SMP Negeri 2 Tanjungbumi.

Model pembelajaran kooperatif yang disarankan bagi guru yang pertama kali menerapkan di kelas adalah Student Teams Achievement Division (STAD) . Student Teams Achievement Division (STAD) merupakan salah satu metode atau pendekatan dalam pembelajaran kooperatif yang sederhana dan baik untuk guru yang baru mulai menggunakan pendekatan kooperatif dalam kelas, STAD juga merupakan suatu metode pembelajaran kooperatif yang efektif (Kristin, 2016:77). Model pembelajaran kooperatif tipe STAD memiliki tahapan yang sederhana sehingga mudah digunakan oleh guru dan beberapa penelitian menyebutkan bahwa model pembelajaran tersebut efektif dalam meningkatkan kualitas proses dan hasil belajar siswa. berdasarkan pertimbangan tersebut, peneliti menggunakan model pembelajaran kooperatif tipe STAD sebagai strategi dalam meningkatkan aktivitas dan hasil belajar IPA siswa kelas VIII SMP Negeri 2 Tanjungbumi. Salah satu ciri STAD adalah pembentukan tim yang saling berkompetisi dalam pembelajaran sehingga setiap anggota tim harus saling membantu agar mampu memperoleh skor personal maupun kelompok maksimal. Hal tersebut senada dengan pernyataan Agustina yang 
menyatakan bahwa gagasan utama STAD adalah untuk memotivasi siswa supaya dapat saling mendukung dan membantu satu sama lain dalammenguasai kemampuan yang diajarkan oleh guru. Menurut Nurhadi (Nurhadi, 2004), keunggulan model pembelajaran kooperatif tipe STAD yaitu: 1) siswa lebih mampu mendengarkan, menerima, dan menghormati orang lain, 2) Siswa mampu mengidentifikasi akan perasaannya juga perasaan orang lain, 3) Siswa dapat menerima pengalaman dan dimengerti orang lain, 4) Siswa mampu menyakinkan dirinya untuk orang lain dengan membantu orang lain dan menyakinkan dirinya untuk saling memahami dan mengerti, 5) Siswa mampu mengembangkan potensi individu yang berhasil guna dan berdaya guna, kreatif, bertanggungjawab, mampu mengaktualisasikan, dan mengoptimalkan dirinya terhadap perubahan yang terjadi.

Model pembelajaran kooperatif memadukan dua konsep pembelajaran, yaitu individu dan kelompok. Dengan demikian, siswa secara mandiri mengembangkan kompetensi individu dan dalam waktu yang bersamaan juga saling membantu sesama individu yang lain dalam kelompok agar mampu berkembang optimal sehingga mendukung pencapaian prestasi secara kelompok. model pembelajaran kooperatif berbeda dengan pembelajaran konvensional yang menggunakan model ceramah dan penugasan dalam setiap proses pembelajaran. Kesenjangan sangat terlihat dalam model pembelajaran konvensional, karena siswa yang memiliki kemampuan intelektual yang tinggi akan memperoleh hasil belajar yang tinggi pula dan sebaliknya siswa yang memiliki kemampuan intelektual rendah akan memperoleh hasil belajar yang rendah pula. Tidak ada ineteraski antar siswa sehingga motivasi belajar masingmasing siswa juga akan mempengaruhi usahanya dalam mencapai tujuan pembelajaran. hal tersebut sesuai dengan pernyataan Suryosubroto (Suryosubroto, 2002) yang mengatakan bahwa model pembelajaran konvensional cenderung dimulai dengan apersepsi, penyajian informasi, pemberian soal-soal dan tugas, kemudian membuat kesimpulan sehingga pembelajaran berpusat pada guru interaksi diantara siswa kurang, dan tidak ada kelompokkelompok kooperatif.

\section{Kesimpulan}

Mengacu pada proses pengumpulan data penelitian menggunakan instrumen penelitian yang valid dan reliabel serta analisis data menggunakan rumus statistik, maka kesimpulan penelitian diuraikan sebagai berikut; (1) Terdapat pengaruh model cooperative learning Student Team Achievement Division (STAD) terhadap aktivitas belajar IPA siswa Kelas VIII SMP Negeri 2 Tanjungbumi; dan (2) Terdapat pengaruh model cooperative learning Student Team Achievement Division (STAD) terhadap hasil belajar IPA siswa Kelas VIII SMP Negeri 2 Tanjungbumi.

\section{Saran}

Saran dari hasil penelitian ini yakni bagi para peneliti lain yang meneliti topik yang relatif sama dengan peneliti untuk meneliti tentang STAD menggunakan pendekatan kualitatif serta dihubungkan dengan variabel lain yang, yaitu pendekatan saintifik, penilaian berbasis proyek dan eksperimen di luar kelas agar mampu memberikan referensi penelitian lebih banyak dalam upaya pengembangan kompetensi IPA siswa.

\section{Daftar Pustaka}

Agustina, R, L. (2018). Upaya Meningkatkan Hasil Belajar Ipa Siswa Kelas Iv Menggunakan Model STAD Dan NHT. Journal of EST, 3(1), 31-38.

Djamarah, S. B. (2012). Psikologi Belajar. Jakarta: Rineka Cipta. 
Indrayani, R. (2014). Penggunaan Komik IPA Terpadu untuk Meningkatkan Penguasaan Konsep dan Retensi Siswa SMP Pada Tema Makanan, Pencernaan dan Kesehatan. Retrieved from http://repository.upi.edu/7285/

Kristin, F. (2016). Efektivitas Model Pembelajaran Kooperatif Tipe STAD ditinjau dari Hasil Belajar IPS Siswa Kelas 4 SD. Jurnal Scholaria, 6(2), 74-79.

Muldayanti, N, D. (2013). Pembelajaran Biologi Model STAD Dan TGT Ditinjau Dari Keingintahuan Dan Minat Belajar Siswa. Jurnal Pendidikan IPA Indonesia, 2(1).

Negoro, S, T. (2004). Anak Super Normal dan Pro Pendidikan. Jakarta: Bina Aksara.

Nurhadi. (2004). Pembelajaran Kontekstual dan Penerapannya dalam KBK. Malang: Universitas Negeri Malang.

Nurmala, D. (2014). Pengaruh Motivasi Belajar Dan Aktivitas Belajar Terhadap Hasil Belajar Akuntansi. Jurnal Pendidikan Ekonomi UNDHIKSA, 4(1), 1-10.

Poerwanto, N. (2007). Psikologi Pendidikan. Bandung: PT Rosda Karya.

Puskur. (2006). Kurikulum Tingkat Satuan Pendidikan. Jakarta: Departemen Pendidikan Nasional.

Suryosubroto. (2002). Proses Belajar Mengajar Di Sekolah. Jakarta: Rineka Cipta. 